\title{
Mapping potential fishing zones based on sea surface temperature and Chlorophyll-A in the Waters of Aceh Besar, Indonesia
}

\author{
Muhammad Muhammad ${ }^{1,2}$, Agus Widi Priana ${ }^{1,3}$, Junaidi M. Affan ${ }^{1,2}$, Haekal Azief Haridhi ${ }^{1,2}$, Irwan Irwan $^{1,2}$, Syarifah \\ Meurah Yuni ${ }^{4}$, Ichsan Setiawan ${ }^{1,2 *}$ \\ ${ }^{1}$ Departement of Marine Sciences, Faculty of Marine and Fisheries, Universitas Syiah Kuala, Banda Aceh 23111, Indonesia \\ ${ }^{2}$ Research Center for Marine and Fisheries, Universitas Syiah Kuala, Banda Aceh 23111, Indonesia \\ ${ }^{3}$ Ocean Diving Club, Universitas Syiah Kuala, Banda Aceh 23111, Indonesia \\ ${ }^{4}$ Departement of Mathematics, Faculty of Mathematics and Natural Sciences, Universitas Syiah Kuala, Banda Aceh 23111, Indonesia
}

\begin{abstract}
Utilization of potential fishery and marine resources is still not maximally used by fishermen. Sea surface temperatures and the spread of chlorophyll-a through remote sensing systems can be used as potential fishing zones. This study aims to determine potential fishing zones using geographic information systems through the distribution of sea surface temperatures and the value of chlorophyll-a concentrations in Aceh Besar waters which is expected to improve the sustainability of fishing efforts. This research was conducted in January-December 2019 using geographic information system by extracting from AquaMODIS satellite image with resolution of $4 \mathrm{~km}$ and sea surface temperature overlay method with chlorophyll-a concentration. The results found the highest sea surface temperature value was in April at $31.62^{\circ} \mathrm{C}$ and the lowest temperature was in December at $28.45^{\circ} \mathrm{C}$. The highest average chlorophyll-a concentration in Aceh Besar waters was $1.53 \mathrm{mg} / \mathrm{m} 3$ in December and the lowest concentration of chlorophyll-a in June and September was $0.20 \mathrm{mg} / \mathrm{m} 3$. Suspected potential fishing zones during January to December 2019 were found as many as 62 potential fishing zones, namely in the Western, Northwest and Eastern waters of Aceh Besar. The most zones are in December as many as eight zones, namely in the Western, Northwest and East parts of Aceh Besar waters and the least found in July as many as one zone that is in the Western part of Aceh Besar waters. When compared to fishing operations areas, the potential fishing zone is in the western part of Aceh Besar waters.
\end{abstract}

\section{Introduction}

Aceh Besar Regency is the westernmost region after Sabang City. Geographically, Aceh Besar Regency is located at coordinates $5.05^{\circ}-5.75^{\circ}$ North Latitude and $94.99^{\circ}-95.93^{\circ}$ East Longitude. To the north it is bordered by the Malacca Strait and Banda Aceh City, to the south by Aceh Jaya Regency, to the east by Pidie Regency, and to the west by the Indian Ocean. Aceh Besar Regency has a coastline of $296.16 \mathrm{~km}$ and a sea area of $1,351.01 \mathrm{~km} 2$ [1].

Aceh Besar District has a large potential for natural wealth, specially in the field of fisheries with a potential of around 5,158 tons/year [2]. The lack of technology used by fishermen, resulted in the utilization of the potential of fisheries and marine resources less than the maximum. The problem that is commonly faced in the utilization of fish resources is the existence of dynamic fishing areas, always changing and moving following changes in environmental parameters [3].

Fishermen usually determine the catch zone by looking at the foam or ripples on the sea surface and by looking at the birds flying on the sea surface. The abundance of fish in an area can also be predicted based on the oceanographic conditions of the waters [4]. Oceanographic conditions that greatly affect the abundance of fish are the distribution of chlorophyll-a and sea surface temperature. The location of waters with high chlorophyll-a content can be indicated in these waters rich in fish because the location is rich in food [5]. Meanwhile, Sea Surface Temperature (SST) is one of the factors that affect the life of organisms in the ocean, because temperature can affect the metabolism and reproduction of organisms in the sea. Each type of fish has a different tolerance to SST for their survival [6].

One way to make it easier for fishermen to find fishing locations, fishermen must have a map of areas that have the potential to carry out fishing operations. Remote sensing technology can determine water areas that have the potential for profitable fish resources. By knowing the sea surface temperature and the distribution of chlorophyll-a through remote sensing systems, it is possible to predict Potential Fishing Zones (PFZ) [7].

\section{Materials and Methods}

\subsection{Time and location}

This research was carried out by monitoring sea surface temperature (SST) and chlorophyll-a from January 2019 to December 2019 in the sea waters of Aceh Besar. Geographically, the research location is located at the coordinates as shown in Figure 1. The tools and materials used in this research are Personal Computer (PC), SeaDAS Software, and ArcGIS Software.

\footnotetext{
*Corresponding author : ichsansetiawan@unsyiah.ac.id
} 


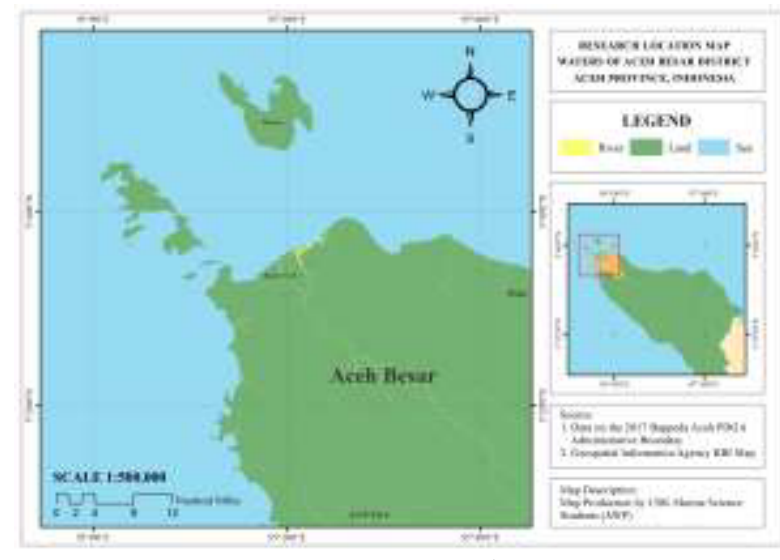

Fig. 1. Research map

\subsection{Research data}

The research data collected includes fishing grounds obtained by interviewing fishermen and image data from the Aqua-MODIS satellite in the form of chlorophyll-a (OCI Algorithm) and monthly sea surface temperatures from January 2019 to December 2019. The image data used is Browser Level data. 3 with a spatial resolution of $4 \mathrm{~km}$. Satellite image data is accessed from the website www.oceancolor.gsfc.nasa.gov.

\subsection{Estimated fishing area}

If a water with a sea surface temperature range between $24^{\circ} \mathrm{C}-27^{\circ} \mathrm{C}$, is categorized as potential, the sea surface temperature range between $27^{\circ} \mathrm{C}-30^{\circ} \mathrm{C}$ is categorized as moderate and the temperature range is less than $24^{\circ} \mathrm{C}$ and more than $30^{\circ} \mathrm{C}$, then the water is categorized as less potential. Meanwhile, if the chlorophyll-a content in the waters is greater than $0.2 \mathrm{mg} / \mathrm{m}^{3}$, it is categorized as potential, the chlorophyll-a content $0.1 \mathrm{mg} / \mathrm{m}^{3}-0.2$ $\mathrm{mg} / \mathrm{m}^{3}$ is categorized as moderate and the chlorophyll-a content is less than $0.1 \mathrm{mg} / \mathrm{m}^{3}$ (Table 1).

Table 1. PFZ assessment through SST and Cholorophyll-a indicators

\begin{tabular}{|c|l|c|c|}
\hline No & $\begin{array}{c}\text { PFZ } \\
\text { Category }\end{array}$ & $\begin{array}{c}\text { Temperature } \\
\text { Criteria }\left({ }^{\circ} \mathrm{C}\right)\end{array}$ & $\begin{array}{c}\text { Chlorophyll-a } \\
\text { Criteria }\left(\mathrm{mg} / \mathrm{m}^{3}\right)\end{array}$ \\
\hline 1 & Potential & $24-27$ & $>0.2$ \\
\hline 2 & $\begin{array}{l}\text { Medium } \\
\text { potential }\end{array}$ & $27-30$ & $0.1-0.2$ \\
\hline 3 & $\begin{array}{l}\text { Less } \\
\text { potential }\end{array}$ & $<24->30$ & $<0.1$ \\
\hline
\end{tabular}

Source : [8], [9], [10]

\subsection{Research procedure}

1. Primary data was collected through direct interviews with 10 fishermen.

2. Secondary data was taken in the form of images of sea surface temperature and chlorophyll-a from MODIS (Moderate Resolution Imaging Spectroradiomater) satellite imagery.

3. Cropping is done according to the desired area which includes the waters of Aceh Besar.
4. The process of extracting information from each image using the Seadas 7.5 application, which produces ASCII data on the distribution of chlorophyll-a and SST distribution in Aceh Besar waters as well as tabulated data on the distribution of chlorophyll-a and SST values for each pixel and its coordinates.

5. The interpolation process is carried out to get the value in the empty area (empty pixels).

6. Overlay is performed to combine the contour of the sea surface temperature image and the contour of the chlorophyll-a distribution image.

7. Map of potential fishing zones in Aceh Besar waters is made.

\section{Results and Discussion}

\subsection{Characteristics of sea surface temperature}

Sea surface temperature (SST) can be used to determine potential fishing zones in an area. The distribution of sea surface temperatures in the waters of Aceh Besar from January to December 2019 based on the results of MODIS satellite image extraction has varying values. The SST value in the waters of Aceh Besar can be seen in Figure 2.

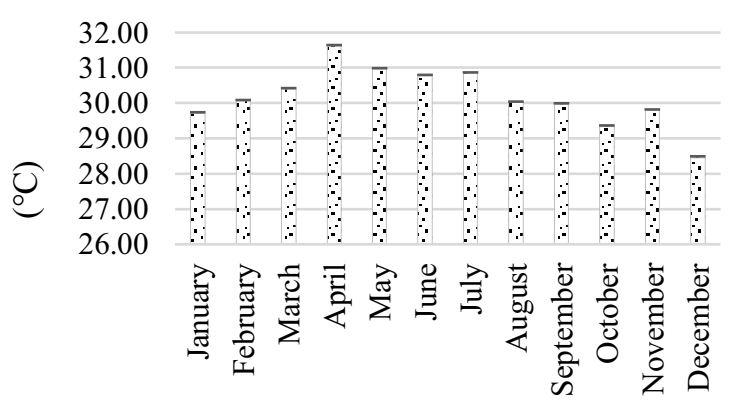

Fig. 2. Characteristics of sea surface temperature

The results of MODIS satellite image data extraction show that the highest SST value is in April, which is $31.62^{\circ} \mathrm{C}$. The lowest temperature was detected in December at $28.45^{\circ} \mathrm{C}$. The difference in SST values in each month is thought to be caused by differences in weather, season and rainfall. The water temperature becomes low when the rainfall is high [11]. Sea surface temperature in waters can also be influenced by patterns of movement of the sun, wind, and air pressure [12].

\subsection{Characteristics of chlorophyll-a}

Chlorophyll-a can be used to determine potential fishing zones, where chlorophyll-a can determine the fertility of a waters. The concentration of chlorophyll-a in the waters of Aceh Besar from January to December 2019 based on MODIS satellite image extraction has varied values. The concentration of chlorophyll-a in the waters of Aceh Besar can be seen in Figure 3. 


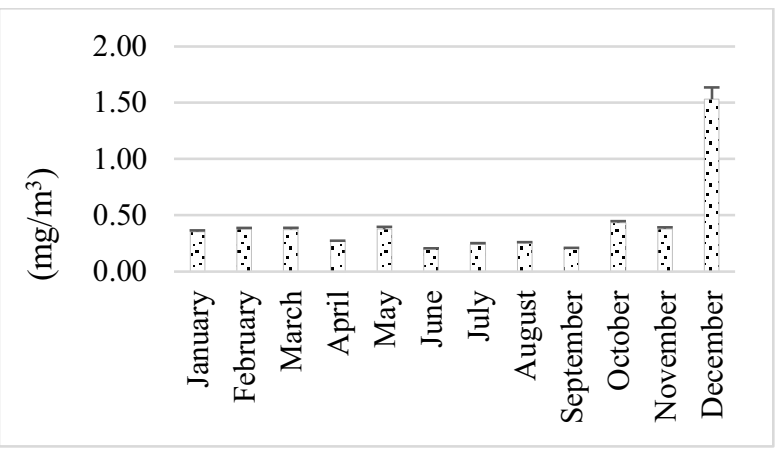

Fig. 3. Chlorophyll-a

The results of MODIS satellite image extraction show that the highest average value of chlorophyll-a concentration in Aceh Besar waters is in December, which is $1.53 \mathrm{mg} / \mathrm{m}^{3}$. The lowest concentration of chlorophyll-a was in June and September at $0.20 \mathrm{mg} / \mathrm{m}^{3}$. High and low concentrations of chlorophyll-a are thought to be caused by currents. Chlorophyll-a is a green pigment found in phytoplankton where the movement of phytoplankton is strongly influenced by currents [13]. Fish react directly to the current by orienting themselves directly to the current [14].

\subsection{Estimation of potential fishing zones}

The results of the estimation of potential fishing zone are shown in Figures 4 to 14. Based on the results of the study, the number of potential fishing zones each month has different values. In January there were 6 potential fishing zones with SST ranging from $28.57^{\circ} \mathrm{C}-29.68^{\circ} \mathrm{C}$ classified in the medium category, while the concentration of chlorophyll-a ranged from $0.2 \mathrm{mg} / \mathrm{m}^{3}$ $0.8 \mathrm{mg} / \mathrm{m}^{3}$ belonging to the category potential. In February, there were 6 potential fishing zones with SST ranging from $29.04^{\circ} \mathrm{C}-29.64^{\circ} \mathrm{C}$ belonging to the medium category, while the concentration of chlorophyll-a ranged from $0.4 \mathrm{mg} / \mathrm{m}^{3}-0.7 \mathrm{mg} / \mathrm{m}^{3}$ classified in the middle category. potential category. In March, there were 4 potential fishing zones with SST) in the potential fishing zones ranging from $29.19^{\circ} \mathrm{C}$ $30.11^{\circ} \mathrm{C}$ belonging to the medium category, while the concentration of chlorophyll-a ranged from $0.5 \mathrm{mg} / \mathrm{m}^{3}$ $1,9 \mathrm{mg} / \mathrm{m}^{3}$ belongs to the category of potential.

In April, there were 3 potential fishing zones with SST ranging from $29.84^{\circ} \mathrm{C}-31.30^{\circ} \mathrm{C}$ classified in the medium category, while the concentration of chlorophyll-a ranged from $0.2 \mathrm{mg} / \mathrm{m}^{3}-0.8 \mathrm{mg} / \mathrm{m}^{3}$ classified in the middle category. potential category. In May, there were 5 potential fishing zones with SST ranging from $29.90^{\circ} \mathrm{C}-30.62^{\circ} \mathrm{C}$ belonging to the medium category, while the concentration of chlorophyll-a ranged from $0.4 \mathrm{mg} / \mathrm{m}^{3}-2.3 \mathrm{mg} / \mathrm{m}^{3}$ classified in the middle category. potential category. In June, there were 3 potential fishing zones with SST ranging from $29.18^{\circ} \mathrm{C}-30.32^{\circ} \mathrm{C}$ classified in the medium category, while the concentration of chlorophyll-a ranged from $0.2 \mathrm{mg} / \mathrm{m}^{3}-0.3 \mathrm{mg} / \mathrm{m}^{3}$ classified in the middle category. potential category.
In July, 1 fishing potential zone with SST ranging from $29.97^{\circ} \mathrm{C}-30.34^{\circ} \mathrm{C}$ was found in the medium category, while the chlorophyll-a concentration of $0.4 \mathrm{mg} / \mathrm{m}^{3}$ was classified in the potential category. In August, there were 6 potential fishing zones with SST ranging from $28.83^{\circ} \mathrm{C}-29.65^{\circ} \mathrm{C}$ classified in the medium category, while the concentration of chlorophyll-a ranged from $0.2 \mathrm{mg} / \mathrm{m}^{3}-0.8 \mathrm{mg} / \mathrm{m}^{3}$ classified in the middle category. Potential category. In September, there were 7 potential fishing zones with SST in the fishing potential zone ranging from $28.03^{\circ} \mathrm{C}-29.98^{\circ} \mathrm{C}$ classified as medium category, while the concentration of chlorophyll-a ranged from $0.2 \mathrm{mg} / \mathrm{m}^{3}-0.7 \mathrm{mg} / \mathrm{m}^{3}$ belongs to the potential category.

In October, there were 7 potential fishing zones with SST ranging from $28.13^{\circ} \mathrm{C}-28.88^{\circ} \mathrm{C}$ classified as being in the medium category, while the concentration of chlorophyll-a ranged from $0.3 \mathrm{mg} / \mathrm{m}^{3}-1.4 \mathrm{mg} / \mathrm{m}^{3}$ classified in the middle category. Potential category. In November, 6 fishing potential zones were found with SST in the fishing potential zone ranging from $28.71^{\circ} \mathrm{C}$ - $29.62^{\circ} \mathrm{C}$ classified as medium category, while the concentration of chlorophyll-a ranged from $0.4 \mathrm{mg} / \mathrm{m}^{3}$ $0.7 \mathrm{mg} / \mathrm{m}^{3}$ belongs to the potential category. In December, there were 8 potential fishing zones with SST ranging from $26.74^{\circ} \mathrm{C}-29.47^{\circ} \mathrm{C}$ and classified as being in the medium category, while the concentration of chlorophyll-a ranged from $0.4 \mathrm{mg} / \mathrm{m}^{3}-8.5 \mathrm{mg} / \mathrm{m}^{3}$ classified as in the potential category.

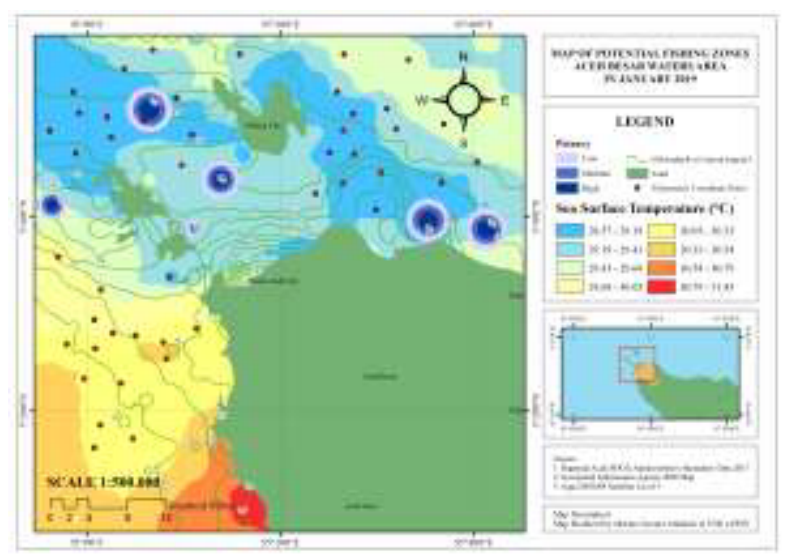

Fig 4. Estimation of potential fishing zones in January

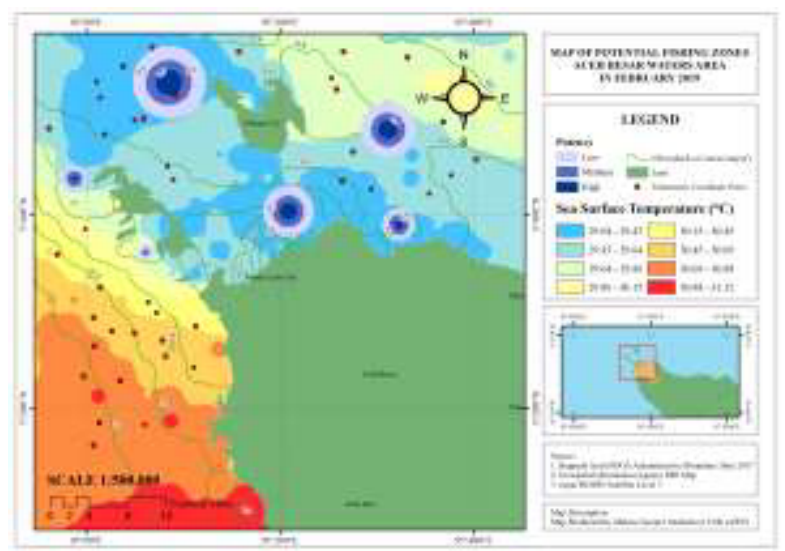

Fig. 5. Estimation of potential fishing zones in February 

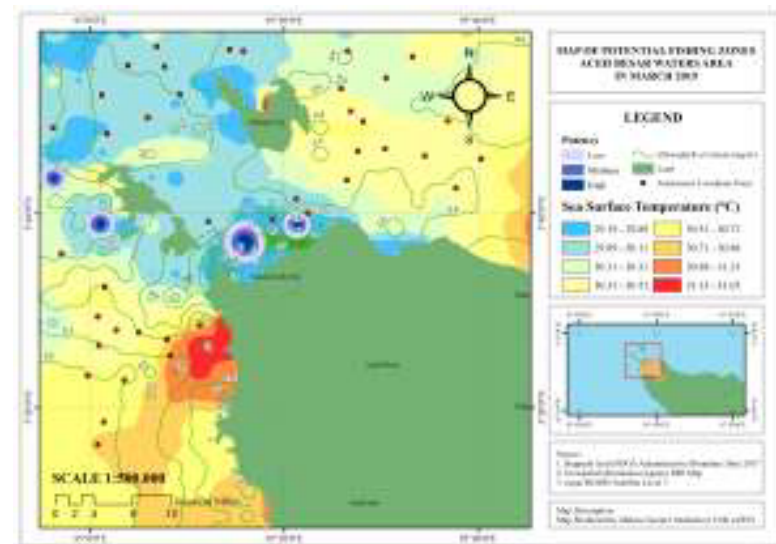

Fig. 6. Estimation of potential fishing zones in March
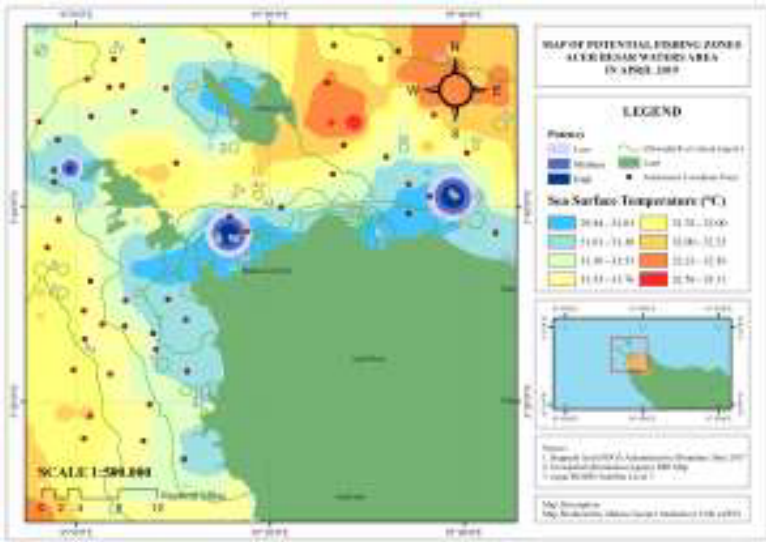

Fig. 7. Estimation of potential fishing zones in April
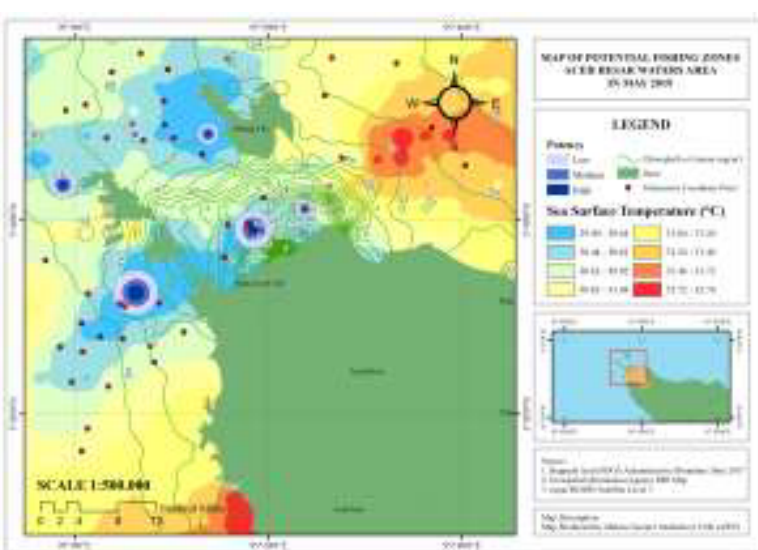

Fig. 8. Estimation of potential fishing zones in May

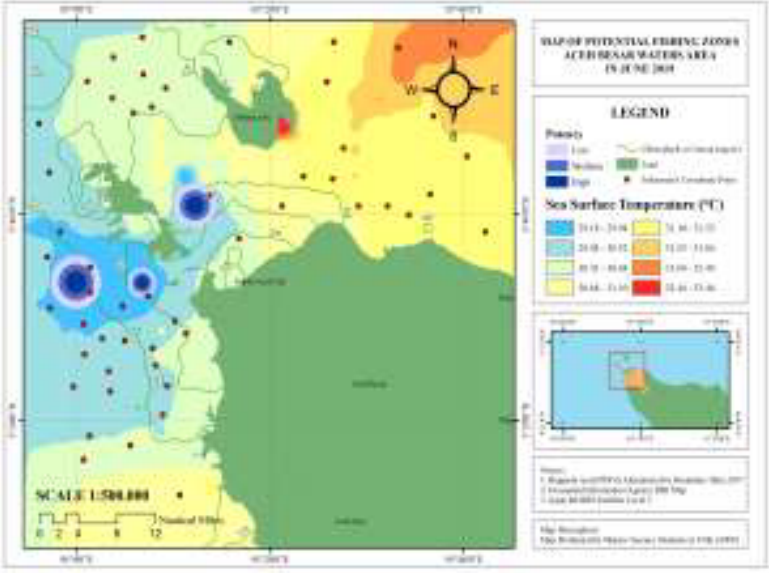

Fig. 9. Estimation of potential fishing zones in June

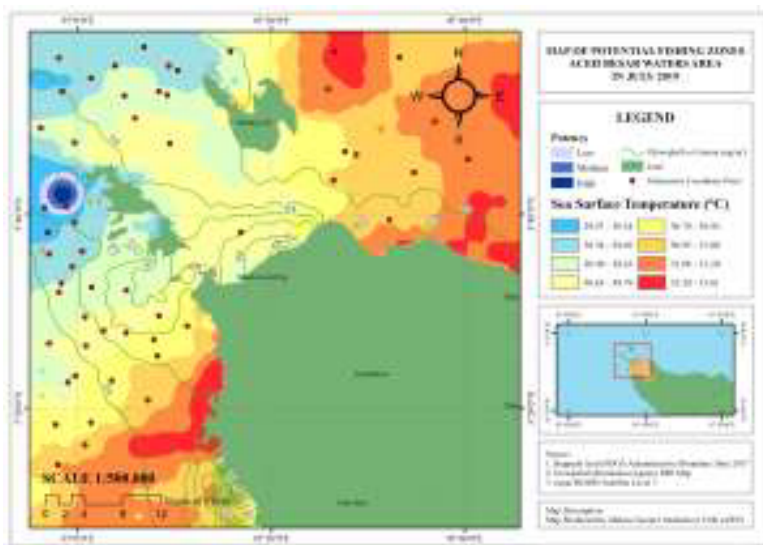

Fig. 10. Estimation of potential fishing zones in July

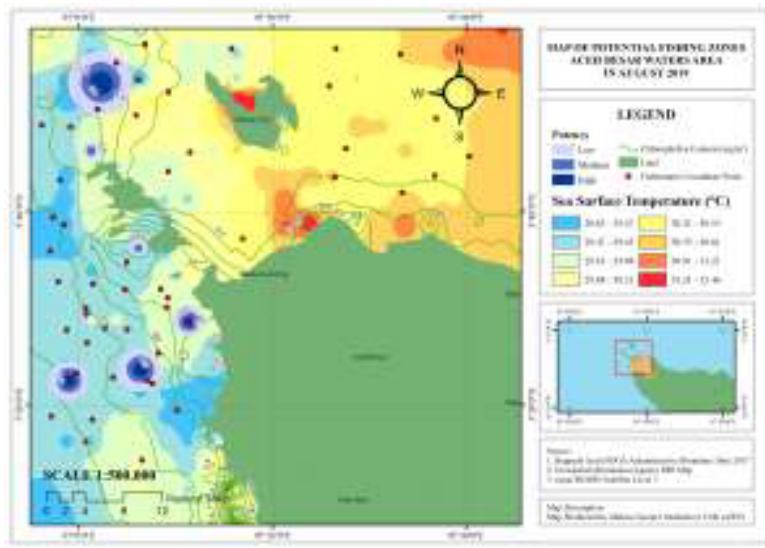

Fig. 11. Estimation of potential fishing zones in August

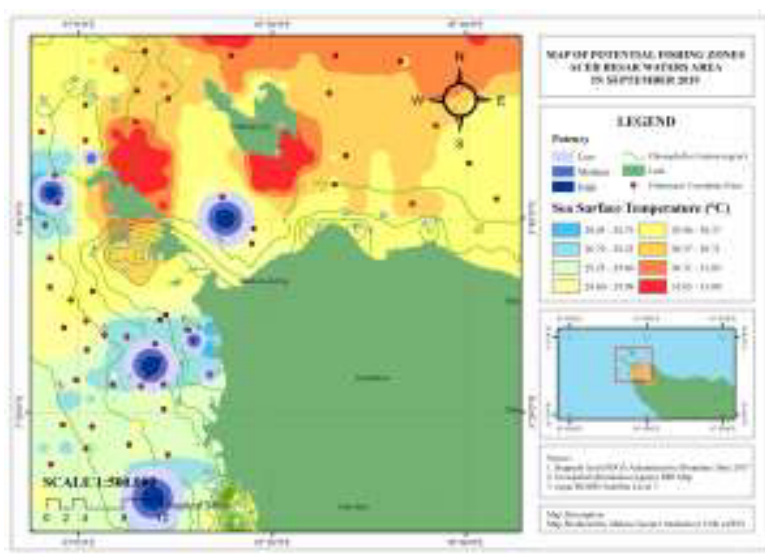

Fig. 12. Estimation of potential fishing zones in September

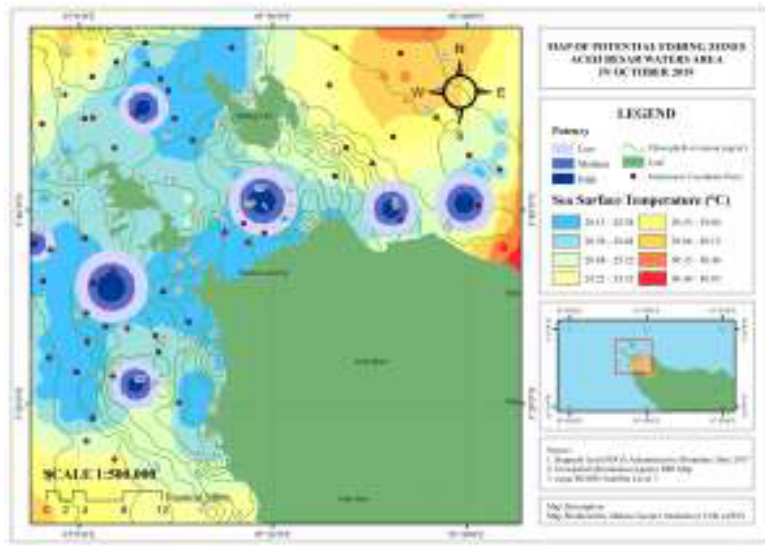

Fig. 13. Estimation of potential fishing zones in October 


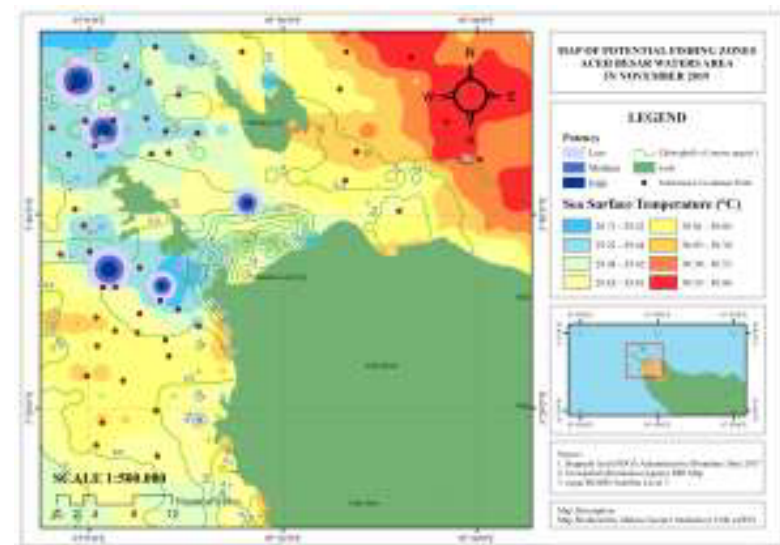

Fig. 14. Estimation of potential fishing zones in November

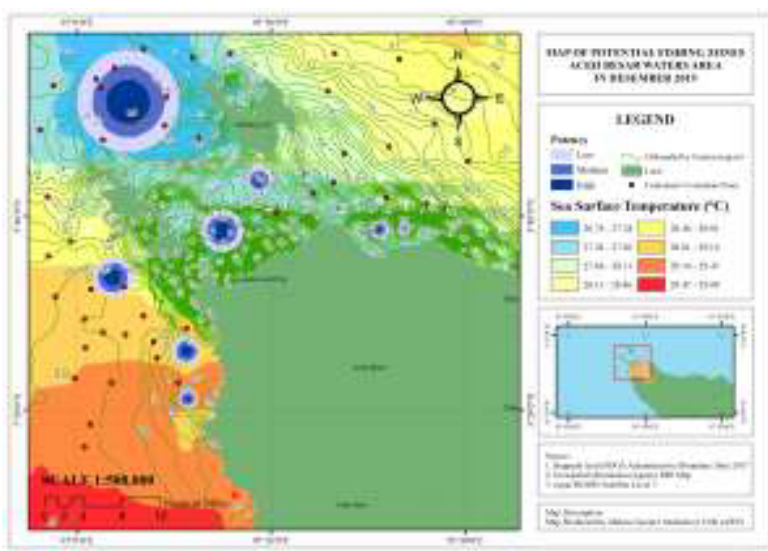

Fig. 15. Estimation of potential fishing zones in December

\subsection{Fisherman's fishing operation area}

Potential fishing zones based on sea surface temperature and chlorophyll-a that have been analyzed are validated with data from the fishing operation area of fishermen in Aceh Besar. The results of data analysis based on the fishing grounds of fishermen in Aceh Besar differ from the results of data analysis conducted through the Geographic Information System based on sea surface temperature and chlorophyll-a.

The fishing grounds of fishermen are spread over almost all temperature ranges and the amount of chlorophyll-a, which is different from the results of potential fishery zones obtained based on SST and chlorophyll-a from MODIS satellite imagery data. This can be influenced by several factors, one of which is currents that can directly or indirectly affect the marine environment and the biota that live in it, including the distribution of fish [15]. In addition, currents also affect small pelagic fish and the stability of the fishing gear used by fishermen [16]. Another influential factor is other oceanographic factors. The distribution of pelagic fish is strongly influenced by oceanographic conditions, such as temperature, salinity, surface currents, and dissolved oxygen [17].

\section{Conclusion}

The conclusion of this research is that the highest sea surface temperature is in April, which is $31.62^{\circ} \mathrm{C}$ and the lowest temperature is in December, which is $28.45^{\circ} \mathrm{C}$.
MODIS satellite image extraction results show the highest average value of chlorophyll-a concentration in Aceh Besar waters is in December, which is $1.53 \mathrm{mg} / \mathrm{m}^{3}$ and the lowest chlorophyll-a concentration is in June and September, which is $0.20 \mathrm{mg} / \mathrm{m}^{3}$. The estimation of potential fishing zones during January to December 2019 found as many as 62 potential fishing zones. The most zones were found in December as many as 8 zones and the least found in July as many as 1 zone.

Acknowledgment. The authors would like to thank the fishermen at TPI Lampulo who have been willing to provide information regarding fishing operation areas and to the Ocean Diving Club of Universitas Syiah Kuala (USK) for providing additional information related to Geographic Information Systems and all parties involved directly or indirectly involved We cannot mention one by one.

\section{References}

1 BPS, Kabupaten Aceh Besar dalam angka, Aceh Besar (2019)

2 DKP Aceh, Potensi usaha dan peluang investasi di Provinsi Aceh (2019)

3 F. Prastianto, Jurnal Ilmu Perikanan Tropis, 21(2) (2016)

4 Mursyidin, K. Munadi, Z. A. Muchlisin, Jurnal Rekayasa Elektrika, 11(5) (2015)

5 D. Simbolon, Silvia, P.I. Wahyuningrum, Marine Fisheries, 4(1) (2013)

6 Kurnia, S. Purnawan, T. Rizwan, Jurnal Ilmiah Mahasiswa Kelautan dan Perikanan Unsyiah, 1(2) (2016)

7 M. F. Hafiz, T. Imam, A. W. Bambang, Journal of Fisheries Resources Utilization Management and Technology, 6(4) (2017)

8 Bukhari, W. Adi, Kurniawan, Jurnal Sumberdaya Perairan, 11(1) (2017)

9 B. Hasyim. Makalah Pribadi Pengantar Kefalsafahan Sains. Sekolah Pasca Sarjana, IPB. Bogor. (2004)

10 Widodo, J. Prosiding seminar validasi data inderaja untuk Bidang Perikanan. Badan Pengkajian dan Penerapan Teknologi. Jakarta. (2019)

11 I. Shadiqin, M. Musman, A. Rahmah, Jurnal Ilmiah Mahasiswa Kelautan dan Perikanan Unsyiah, 1 (3) (2016)

12 K. Wyrtki, Physical oceanography of the southeast ecosystem, California (1961)

13 T. D. Kuswanto, M. L. Syamsuddin, Sunarto, Jurnal Perikanan dan Kelautan, 8(2) (2017)

14 M. P. M. Reddy, Influence of the various oceanographic parameters on the abundance of fish catch in Proceeding of International workshop on Aplication of Satellite Remote Sensing for Identifying and Forecasting Potential Fishing Zones in Developing Countries, India (1993)

15 M. S. Wibisono, Pengantar ilmu kelautan, Grasindo, Jakarta (2005)

16 A. R. Jalil, Depik, 2(1) (2013) 
17 Edmondri, Studi penangkapan ikan cakalang dan madidihang di perairan Sumatera Barat pada musim timur, Skripsi, Institut Pertanian Bogor, Bogor (1999) 